\title{
INTEGRATION IN TOURISM DISTRIBUTION CHANNELS AND BARGAIN POWER OF TOUR OPERATORS OVER ACCOMMODATION ESTABLISHMENTS: TUI AND THOMAS COOK CASES
}

\author{
MUSTAFA BOZ \\ Canakkale Onsekiz Mart University, TURKEY \\ e-mail: mboz@comu.tr
}

KEYWORDS

ABSTRACT tour operators, mergers in tourism, vertical-horizontal integration, tourism marketing, sustainable tourism marketing, accomodation establishments

Nowadays, large international tour operators, play an important role in tourism distribution channels. They can significantly affect international tourism flow and dominate accomodation establishments and other businesses particularly in mass leisure tourism. Through mergers and acquisitions in tourism industry market structure also changes.

This study is supported by secondary research focusing on mass tourism distribution channels and the pricing problems arising between tour operators and accomodation establishments. First of all, vertical and horizontal integration in tourism industry is stated through TUI Group and Thomas Cook Group cases which are two of the largest tour operators in Europe. Afterwards, bargain power of tour operators over accommodation establishments is tried to expose. In conclusion, some recommendations are given in the light of literature.

\section{Introduction}

After fifties, due to changes in economic, socio-cultural, and political life such as shorter working weeks, increase in revenues, liberalization of economies and politics, development in infrastructure, and superstructure like new transportation, communication, and accommodation facilities, the middle and lower income level public were able to afford holidays. The number of international tourist arrivals rose from 25 million in 1950, to 435 million in 1990, 675 million in 
2000, 942 million in 2010, 1.1 billion in 2013, and 1.14 billion in 2014 (UNWTO, 2012; UNWTO, 2013; Scowsill, 2015). Cheap package tours are an important driving force in this increase.

Fifties are accepted as the beginning of mass - mainstream tourism and usually called as sun- sand - sea (3S) tourism. Mass tourism is usually organized by tour operators as package tours -nowdays particularly "all inclusive package tours". Due to the sheer quantity and standardisation of package holidays, tour operators generated economies of scale and lower prices for tourists, who started to arrive in mass numbers (Sard et al., 2002, p. 4). In European tourism market more consumers showed interest into package tours, particularly due to lower prices, ease of purchase, tour operator's guarantee. Over time, large international tour operators had central position in tourism industry and started to influence and dominate the market. There is enough evidence to state that large international tour operators have market power in both the tourists' country of origin and in mass destinaton markets (Sard et al., 2002, p. 27). On the other hand, it can be argued that large international tour operators play an essential role in promoting the destination to and delivering tourists from international markets (Klemm, Parkinson, 2001, p. 367). Even, they can effect the image and market structure of a destination.

\section{Distribution Channels and Integration in Mass Tourism}

The primary distribution functions for tourism are information, combination and travel arrangement services (Buhalis, Laws, 2001, p. 8). Large international tour operators promote national and international tours for prospective tourists, provide information, combine tourism services such as transport, transfers, accomodation and sell to end users or market to travel agents as a package tour. Potential of international mass tourism increases over time. For example, $60-80 \%$ of all bookings in the UK and Germany are made through travel agencies (Cook, 2016). Due to financing and organizational powers, tour operators represent one of the most powerful and most influential shareholders in the tourism industry. They have a strong influence on international flows from main generating markets to various destinations (Cavlek, 2002, p. 479; Sard et al., 2002, p. 4). Table 1 shows Europe's largest tour operators in 2012.

Table 1. Europe's largest tour operators -2012

\begin{tabular}{rlcl}
\hline Rank & Name of the tour operator & Revenue (billion Euro) in 2012 & Headquarter of the tour operator \\
\hline 1. & TUI & 18.3 & Germany \\
2. & Thomas Cook & 11.3 & England \\
3. & Kuoni & 4.8 & Switzerland \\
4. & DER Touristik & 4.65 & Germany \\
5. & Costa (cruise firm) & $3.1(2011)$ & Italy \\
6. & FTI & 1.8 & Germany \\
7. & Alltours & 1.6 & Germany \\
8. & Club Med & 1.5 & France \\
9. & Alpitour & 1.0 & Italy \\
10. & Hotelplan & 0.975 & Switzerland \\
\hline
\end{tabular}

Source: FVW (2014). 
In 2015, Kuoni Group's tour operating businesses have been sold to the owner of German operator DER Touristik for an undisclosed sum. The takeover includes Kuoni UK together with tour operations in Switzerland, Scandinavia and the Benelux region (Davies, 2015). By this acquisition, DER Touristik became the third largest tour operator in Europe.

20/80 rule applies in the industry: $20 \%$ of the enterprises represent app. $80 \%$ of total turnover. There is an increasing degree of concentration, both in the subsector of tour operators and travel agents (De Blust, 2009, p. 31). As many scholars agree (Sard et al., 2002, p. 6; Perignon, 2009, p. 10; Gustavo, 2013, p. 16) both German and British tour operators, particularly TUI Group and Thomas Cook Group dominate European tourism market. These, Europe's two leading leisure travel groups, which have combined market shares of more than $50 \%$ in major source markets such as the UK, Scandinavia, Netherlands and Belgium, and more than $30 \%$ of the German market, are well ahead of other major tour operators (FVW, 2014). In 2007, Europe's four leading tour operators consolidate into two after TUI and First Choice Holidays and MyTravel and Thomas Cook mergers German-British combination (Blitz, Atkins, 2014). Major players like Thomas Cook Group and TUI Group are expanding their activities in emerging markets such as e.g. China, Russia and India. Developing a global strategy is driven by a strong need to reach larger volumes, so better deals with e.g. accommodation and airline companies can be negotiated (Perignon, 2009, p. 10).

Both horizontal and vertical integration strategies are to be found within the sector (Klemm and Parkinson, 2001, p. 369; De Blust, 2009, p. 32). Tour operators generally try to maintain their long term profitability and existence through horizontal and vertical integrations. TUI Group and Thomas Cook Group might even merge, creating a giant and saving plenty of money. Alternatively, one of these two big boys might marry a low-cost airline, linking cheap flights with cheap bed (The Economist, 2011).

\section{Methodology}

This study is supported by secondary research focusing on mass tourism distribution channels and the pricing problems arising between tour operators and accomodation establishments. First of all, vertical and horizontal integration in tourism industry is mentioned by TUI Group and Thomas Cook Group cases that are two of the largest tour operators in Europe and the world. Afterworth, bargain power of tour operators over accommodation establishments are tried to be explained. In conclusion, some recommendations are given in the light of literature.

\section{TUI Group and Thomas Cook Group Cases}

TUI Group is the largest tour operator and Thomas Cook Group is the second largest tour operator in Europe. They follow integration strategies both vertically and horizantaly. They have many sub-brands or control many other brands by contracts. 


\section{TUI Group}

TUI Group is Europe's leading travel group. The three sectors TUI Travel (tour operating, online sales, high street outlets, airlines and incoming agencies), TUI Hotels \& Resorts and the cruise ship business form the World of TUI (TUI group, 2014). TUI AG entered the Tourism market in 1997 with the acquisition of one of Germany's leading tourism companies Hapag-Lloyd. Further tourism acquisitions followed and the company started to exit from its industrial businesses. Acquiring some of the biggest names in European tourism including, Thomson, Fritidsresor and Nouvelles Frontières and shareholdings in the hotel groups RIU and Magic Life, TUI AG created one of the world's leading tourism groups (TUI Group, 2016).

In 2000, TUI acquired Thomson Travel Group plc (the UK's market leader for package holidays) and the group was renamed TUI AG in 2002 (Tutor2u, 2007; TUI Group, 2014).

In 2007 TUI AG and another British package-holiday company First Choice Holidays merged their tour operating business to create Europe's largest tour operator as a new force in the European travel industry. The new company, to be called TUI Travel, would have annual revenues of more than $£ 12$ bn and $27 \mathrm{~m}$ customers. It operates in 20 countries, serving more than 200 destinations (Walsh, 2007; Tutor2u, 2007; The Economist, 2011; Blitz, Atkins, 2014).

The deal has formed a business with over 300 hotels, 136 aircrafts and 1,800 shops across Europe selling holidays to 30 million customers in hundreds of countries. Shares in the newly created company, which has taken the TUI Group name (Denton, 2014).

One of cornerstones of TUI optimising vertical integration within the Group, achieving cost efficiency and restructuring unprofitable business units (TUI AG, 2015, p. 8).

TUI Group - overview. Key figures financial year 2012/13 (TUI AG, 2015, pp. 8-11; TUI Group, 2015)

One of the world's leading international leisure travel groups:

- more than 30 million customers from over 30 source markets,

- operating in around 180 destinations across the globe,

- Pan-European airline group with more than 130 aircraft. Five tour operator-airlines flying more than 140 state-of-the-art medium- and long-haul aircraft,

- approx. 1,800 owned retail shops in continental Europe, the UK \& Ireland,

- top online portals in Europe,

- approx. 55,000 employees,

- inbound travel services \& Accommodation OTA brands,

- market leaders in cruise handling and accommodation wholesale,

- $12 \mathrm{~m}$ offline customers and $25 \mathrm{~m}$ room nights sold,

- world's largest provider of specialist and experiential travel,

- delivering range of unique experiences,

- over 90 brands. 
TUI Hotels \& Resorts - At a glance (TUI AG, 2015, p. 16; TUI Group, 2015)

- no. 1 leisure hotelier in Europe with around 300 Group-owned hotels in its own portfolio under premium brands such as Riu and Robinson with 210,000 beds in 24 countries,

- most hotel companies with local partners,

- focus on four star category (about 60\%),

- high occupancy rates $(80 \%)$ as there is access to the customers and direct distribution of TUI Travel.

TUI Cruises is a joint venture (50/50) between TUI AG and the US-shipping company Royal Caribbean Cruises, cruise fleet of 13 ships (TUI AG, 2015, p. 33)

\section{TUI Travel - Mainstream sector}

Market leader across Europe no.1 in UK, Netherlands, Belgium, France, Germany, Austria, no. 2 in Nordic (Scandinavia), no. 3 in Switzerland, Poland (TUI Group, 2016).

\section{TUI Group Brands}

TUI Group owns more than 90 brands. Some of them are as follow (TUI Group, 2016).

Tour operators: Many strong tour operators with leading positions in their own domestic markets are clustered under the roof of the TUI Group. In Germany they include TUI Deutschland, 1-2-FLY, airtours and Wolters Reisen, in the UK Thomson and First Choice. TUI operators are also among the leading national brands in Austria, Poland, Switzerland, Denmark, Finland, Norway, Sweden, France, Belgium, the Netherlands, Russia and the Ukraine.

Airlines: There are six proprietary airlines in the TUI Group operating 136 medium- and long-haul aircraft, including the largest fleet of the latest Boeing Dreamliners. The airlines are TUIfly, Thomson, TUIfly Nordic, Jetairfly, Corsair and ArkeFly, serving more than 180 destinations around the world.

Hotels: TUI Group operates over 300 hotels of its own with 210,000 beds in 24 countries. The facilities run by our brands are located in top-class settings in the holiday-making regions - offering a variety of hotel formats with high standards of business performance, service quality and environmental management. The Group's hotel portfolio includes such well-known brands as Riu and the premium-market Robinson Clubs.

Cruises: TUI Group gears operations to the specific desires of different customers. HapagLloyd Cruises, with four ships, is the leading provider of expedition and luxury cruises in the German-speaking market.The joint venture TUI Cruises offers premium voyages. The fleet currently consists of four vessels. Thomson Cruises has five liners serving the British market. TUI Cruises has even ordered four more ships.

Growth Strategy: TUI Travel PLC has now merged with TUI AG to become TUI Group. Having established a healthy financial footing for the Group over the last 18 months, we are now launching the next phase of oneTUI. In the next few years we intend to expand our portfolio by altogether 60 new hotels and four new ships (TUI Group, 2016). 


\section{Thomas Cook Group}

Thomas Cook is the world's oldest travel firm and the best known name in travel. Thomas Cook began his international travel company in 1841 (Cook, 2016). He created and launched many novelties in tourism industry. Today, Thomas Cook Group plc is one of the world's leading leisure travel groups, with sales of over $£ 9$ billion and more than 20 million customers. The group is supported by c. 27,000 employees and operates from 17 countries. It is number one or two in all its core markets (Tutor2u, 2007; The economist, 2011; Cook, 2015).

In March 2001, Thomas Cook was acquired by C\&N Touristic AG, one of Gernany's largest travel groups. Within a matter of months, C\&N Touristic AG had changed its name to Thomas Cook AG and launched a new logo and brand identity.

On 19 June 2007, Thomas Cook AG a German-owned travel firm, took over MyTravel, a British rival, to create Europe's second-biggest package-tour firm and formed Thomas Cook Group plc.

In October 2011, when Thomas Cook amalgamated its UK high street travel and foreign exchange businesses with those of the Co-operative Group and the Midlands Co-operative Society to create the UK's largest retail travel network of over 1200 shops.

On 1 October 2013 Thomas Cook officially unveiled its new unified brand to the world. The 'Sunny Heart' and 'Let's go!' tagline will form an important part of Thomas Cook's future plans.

As part of rolling out the Sunny Heart Thomas Cook Group has taken the opportunity to concentrate his brand investment, reducing the number of brand labels from 85 to just 30 (Cook, 2015).

Thomas Cook offers cheap package holidays, city breaks, villa holiday, match break, cruise, luxury holiday of a lifetime or simply just cheap flights and hotels (Cook, 2014).This group has seen a large wave of mergers and acquisitions over the years, resulting in a highly concentrated market (Jenkins, 2009, p. 26). Thomas Cook benefit from an omni-channel distribution system for his products, which include retail stores, websites and call centres, as well as third-party travel agents. Access to such a wide variety of distribution channels enables the firm to maximise customer reach and provides choice to his customers (Cook, 2015).

\section{Thomas Cook Group Brands}

Thomas Cook has a wider choice of brands so costumers can satisfy all their needs with a Thomas Cook holiday. Whether they are looking for cheap package holidays, city breaks, villa holiday, match break, cruise, luxury holiday of a lifetime or simply just cheap flights and hotels Thomas Cook has a brand specifically dedicated to it.

Master Brand: Thomas Cook

Aligned Brands: Ving, Tjäreborg, Spies

Endorsed Brands: Condor, Öger Tours, Bucher Last Minute, Airmarin, Airtours, Tourvital, Pegase, Neckermann

Stand Alone Brands Examples: Urlaub Shop, Uguatoi, Club 18-30, Cresta, Directholidays. co.uk, Elegant Resorts, Jet Tours, The Co-operative Travel, Escapades, Hotels4U.com, Manos, Thomas Cook Style Collection, Thomas Cook Signature, Thomas Cook Stores (Cook, 2014). 


\section{Baryain Power of Tour Operators over Accommodation Establishments}

Tourism industry becomes increasingly competitive and based around a distribution system dominated by multinational tour operators. Their ability to negotiate low prices for hotel rooms is not dependent on their ownership of hotels, but on their powerful bargaining position, vis-a-vis individual or group hoteliers (Tapper, 2001, p. 353). Particularly low and middle income consumers show a growing tendency towards all inclusive package tours partly due to the lower prices that tour operators are able to offer and organize all programme. In summary, the more tourists a tour operator is able to bring, the greater market power it has and thus it is more able to negotiate lower prices with the supply side, above all with hoteliers (Sard et al., 2002, p. 27). Table 2 shows techniques used by tour operators in order to reduce prices at accomodation establishmetrs.

Table 2. Nine Techniques Used by Tour Operators in Order to Reduce Prices at accomodation establishmetrs

1. Timing of negotiating contracts-bargaining during low occupancy periods

2. Misquoting customer satisfaction surveys

3. Directing/Misleading tourists to certain properties

4. Short release period which does not allow adequate time for selling unused rooms

5. Over-contracting and renegotiating of prices after low coverage of contracts

6. Structural destination seasonality circle

7. Alter/misleading image for destinations and properties

8. Play hotels and destinations against each other

9. Oligopsony (few buyers) at destinations

Source: Buhalis (2000), pp. 113-139.

\section{Accomodatian establishments' reasons to work with tour operators}

Particularly in mass leisure tourism tour operators are important intermediaries for accomodation establishments. Because:

- Hoteliers want to sell as many bed-nights in advance and also obtain payment in advance. Tour operators provide this opportunity to accomodatian establishments.

- Unless tour operators, accomodatian establishments are not sure of being able to fill their establishments throughout the season.

- Particularly in emerging destinations, a lot of accommodation establishments are erected without any planning. They usually have lack of knowledge and capability to market their establishments themselves.

- Accomodatian establishments neither have fianancial nor organizational power to market their establishments to potential customers.

- Mass tourism customers prefer to buy their holidays from tour operators which sell tours much cheaper, also arranges transport, transfers, activities and any extra services that might be needed. 


\section{Conclusion and Recommendations}

Large International tour operators are powerful intermediaries in the tourism industry, whose role in the development of tourist destinations is subject of controversy. They are for the most part, profit seeking companies for whom the long-term sustainability of a particular destination is secondary, to their business objectives. They direct potential customers and in any negative situation they may easily change accomodation establishments and/ or destinations which they market. The long term effects of which have been largely negative for those in the destination area (Klemm, Parkinson, 2001, p. 367). Some examples of tour operator strategies and their effect on destinations can be given as Table 3 .

Table 3. Tour operator strategies and their effect on destinations

\begin{tabular}{lll}
\hline \multicolumn{1}{c}{ Strategy } & \multicolumn{1}{c}{ Impact } & \multicolumn{1}{c}{ Solution } \\
\hline Vertical & $\begin{array}{l}\text { Access to potential tourists via travel } \\
\text { agency network is difficult }\end{array}$ & $\begin{array}{l}\text { Use smaller operators } \\
\text { Local marketing association }\end{array}$ \\
\hline Branding & $\begin{array}{l}\text { Resort name not featured } \\
\text { Wrong or limited image }\end{array}$ & $\begin{array}{l}\text { National campaings in major target markets } \\
\text { Negotiate with tour operator over name and image }\end{array}$ \\
\hline $\begin{array}{l}\text { Over capacity } \\
\text { in resort }\end{array}$ & Low room rates & $\begin{array}{l}\text { Local planning to control pace and scale of } \\
\text { development } \\
\text { Long- term sustainablity must be main criterion }\end{array}$ \\
& $\begin{array}{l}\text { High-rise development out of scale } \\
\text { with local environment }\end{array}$ & $\begin{array}{l}\text { Negatite beter contract terms } \\
\text { Develop other markets so that not wholly dependent } \\
\text { Late confirmation } \\
\text { and late payment }\end{array}$ \\
& $\begin{array}{l}\text { Cash flow problems } \\
\text { Unpredictable tourist numbers }\end{array}$ & \\
& $\begin{array}{l}\text { Poor hotel sales } \\
\text { Wrong mix of tourists }\end{array}$ & \\
\hline
\end{tabular}

Source: Klemm, Parkinson (2001), pp. 367-375.

Although all inclusive package tours are the most growing segment of mass tourism, are not sustainable and worthwhile for accomodation establishments, other local etreprises, and host communities. Because, large international tour operators are able to dominate and direct local enterprises and destination. Besides, in this system economic leakages are in maximum level. Large tour operators from tourist sending developed countries gain more than host companies, owing to foreign investment, tour operators, air transport, export goods and organizations etc. To be able to benefit more from tourism industry, accomodation establishments, other host businesses, and destination organisations must develop sustainable tourism marketing strategies. For example; they have to create alternative, genuine, authentic tourism products to attact high income level tourists. They must develop their own marketing agencies, tour operators, airways etc. Sustainable, community based tourism politics must be developed and implemented. 


\section{References}

Blitz, R., Atkins, R. (2014). TUI and First Choice Agree Merger. Available at: http://www.ft.com/cms/s/0/815b3cce-d58311db-a5c6-000b5df10621.html\#axzz3Jbhadjo4 (20.11.2014).

Buhalis, D., Laws, E. (2001). Tourism Distribution Channels: Practices, Issues and Transformations. Cengage Learning EMEA.

Cavlek, N. (2002). Tour Operators and Destination Safety. Annals of Tourism Research, 29 (2), $478-496$.

Cook, T. (2014). Thomas Cook - Partner Brands. Available at: http://www.thomascook.com/brands (6.12.2014).

Davies, P. (2015). Kuoni Tour Operator Sold to DER Touristik Parent. Available at: http://www.travelweekly.co.uk/articles/54638/kuoni-tour-operator-sold-to-der-touristik-parent (22.06. 2015).

De Blust, M. (2009). Study on the competitiveness of the EU tourism-industry Face to face interview European Travel Agents and Tour Operators Associations (ECTAA) Brussels, 23 March 2009. Ref. Ares(2014)74820 - 15/01/2014. FN97613 - FWC Sector Competitiveness - EU tourism-industry.

Gustavo, N. (2013). Marketing Management Trends in Tourism and Hospitality Industry: Facing the 21st Century Environment. International Journal of Marketing Studies; 5 (3). DOI: 10.5539/ijms.v5n3p13.

Klemm, M., Parkinson, L. (2001). UK Tour Operator Strategies: Causes and Consequences. International Journal of Tourism Research, 3, 367-375. DOI: 10.1002/jtr.351.

Perignon, C. (2009). Study on the competitiveness of the EU tourism-industry Face to Face Interview Association of Belgian Tour Operators (ABTO) Zaventem, 8 April 2009. Ref. Ares(2014)74820 - 15/01/2014. FN97613 - FWC Sector Competitiveness - EU tourism-industry.

Sard, M., Aguiló, E., Alegre, J. (2002). Analysis of Package Holiday Prices in the Balearic Islands. Document de Treball, 40 .

Scowsill, D. (2015). Travel \& Tourism Economic impact 2015, United Kingdom. Report of WTTC. Foreword. The Authority on World Travel \& Tourism.

Tapper, R. (2001). Tourism and Socio-economic Development: UK Tour Operators' Business Approaches in the Context of the New International Agenda. International Journal of Tourism Research, 3, 351-366. DOI:10.1002/jtr.348.

The Economist (2011). Horrible holidays. Tour operators. Available at: http://www.economist.com/node/21525904 (13.08.2011).

Thomas Cook (2015). Key Industry Trends: December 2013. Available at: https://www.thomascook.com/brands (10.11.2015).

Thomas Cook 2016. Booking in UK and Germany. Available at: http://annualreport2015.thomascookgroup.com/casestudies (11.02.2016).

TUI Group (2015). Who we are? Available at: http://www.tuigroup.com/en-en/investors/tui-group-at-a-glance/who-weare (13.12.2015).

TUI Group (2014). Group Profile. Available at: https://www.tui-group.com/en/company/profile (6.12.2014).

TUI Group (2016). At a glance. Available at: https://www.tuigroup.com/en-en/about-us/at-a-glance (11.02.2016).

Tutor2u (2007). Merger Mania Grips the Travel Industry. Available at: www.tutor2u.net/cafe/default.php (02.05.2014).

UNWTO (2012). UNWTO (World Tourism Organization) Annual Report 2011. Madrid: UNWTO.

UNWTO (2013). UNWTO (World Tourism Organization) Annual Report 2012. Madrid: UNWTO. 


\section{INTEGRACJA KANAŁÓW DYSTRYBUCJI JAKO OKAZJA WZMOCNIENIA SIŁY TUROPERATORÓW WOBEC OBIEKTÓW NOCLEGOWYCH \\ - STUDIUM PRZYPADKU TUI I THOMAS COOK}

SŁOWA KLUCZOWE

STRESZCZENIE touroperatorzy, fuzje w turystyce, integracja pionowa, integracja pozioma, marketing w turystyce, zrównoważona turystyka, obiekty noclegowe

Duże międzynarodowe grupy touroperatorskie odgrywają ważną rolę w turystycznych kanałach dystrybucji. Mogą one znacząco wpływać na międzynarodową turystykę; zdominowały obiekty zakwaterowania oraz inne firmy, zwłaszcza zajmujące się masową turystyką wypoczynkową. Dzięki fuzji i przejęciom w branży turystycznej, zmienia się także struktura rynku. Badania przedstawione w artykule poparte są badaniami wtórnym i koncentrują się na masowych kanałach dystrybucji usług turystycznych i problemach dotyczących kształtowania cen między organizarorami turystyki a obiektami zakwaterowania. W artykule przedstawiona jest przede wszystkim integracja pionowa i pozioma w branży turystycznej na przykładzie TUI i Thomas Cook Group, największych touroperatorów w Europie. 